DOI: $10.20472 / S S .2016 .5 .4 .005$

\title{
PROSECUTING RAPE, SEXUAL ENSLAVEMENT, AND GENOCIDE IN TIME OF WAR: SOUTHEASTERN EUROPE 1991-1995
}

\author{
DOROTHY S. MCCLELLAN, NIKOLA KNEZ
}

\begin{abstract}
:
This paper addresses the experiences and concerns of the 20,000-50,000 women who were raped and sexually enslaved in the war in Southeastern Europe and are still awaiting prosecution of their victimizers. Through interviews with survivors and experts, we document the challenges faced by those seeking official status as victims of war crimes entitled to moral, spiritual, and financial assistance. The paper examines the record of the U.N.'s International Criminal Tribunal for the former Yugoslavia (ICTY) and the courts of Bosnia-Herzegovina and Croatia in combating impunity for conflict-related sexual violence by successfully prosecuting the crimes. Our findings suggest that the ICTY's application of the concepts of 'joint criminal enterprise' and 'moral equivalency' resulted in a limited record of successful prosecution and an uncertain political future for the region.
\end{abstract}

\section{Keywords:}

war crimes, sexual violence, conflict-related sexual violence, women and rape, ethnic cleansing, prosecution of genocide, Balkans, rape victims

JEL Classification: D74, K33, K42

\section{Authors:}

DOROTHY S. MCCLELLAN, Texas A\&M University-Corpus Christi, United States, Email: dorothy.mcclellan@tamucc.edu NIKOLA KNEZ, 21st Century Society for Human Rights \& Education, United States, Email: nikolaknez@ifilms-fx.com

\section{Citation:}

DOROTHY S. MCCLELLAN, NIKOLA KNEZ (2016). Prosecuting Rape, Sexual Enslavement, and Genocide in Time of War: Southeastern Europe 1991-1995. International Journal of Social Sciences, Vol. V(4), pp. 79-102., 10.20472/SS.2016.5.4.005 


\section{Introduction}

As people around the globe mark the 25th anniversary of the start of the war in the countries of the former Yugoslavia, we recall a terrible war of aggression that shocked the conscience of the modern world by its deliberate carnage, primitivism, and countless atrocities. No one can forget the images and reports brought to our attention by the media: of concentration camps, ethnic cleansing, mass graves, starving prisoners, sex camps, tens of thousands of rape victims, Sarajevo's four-year siege, citizens marched to their deaths in Vukovar, the shelling of the medieval city Dubrovnik, thousands of innocents murdered in Srebrenica, destroyed towns and religious sites, burned libraries, and shelled museums. Nor can we forget the courage of those who fought against evil and died in the war, and those who endured bizarre indignities and managed to survive.

This paper addresses the experiences and concerns of tens of thousands of women who were raped in that war and are still awaiting prosecution of their victimizers, many still seeking official status as victims of war crimes entitled to moral, spiritual, and financial assistance. The aggressors carried out vicious crimes deliberately targeting the civilian population. The widespread, systematic use of rape as an instrument of war by the Serbian military (1991-1995) has been documented by the U.N. and the International Tribunal for the former Yugoslavia (ICTY). Scholars estimate that between 20,000 and 50,000 women were raped by the Serbian military (Stiglmayer, et al., 1994, p. 85; Parrot and Cummings, 2008 , p. 39). To date, however, there has been no coordinated attempt to create a database of these victims and only a handful of individuals have been prosecuted. The victims are alone in their suffering. The criminals live freely among them, having rarely paid any price for their crimes.

This paper examines the record of the U.N. Security Council's International Criminal Tribunal for the former Yugoslavia (ICTY), as well as the courts of Bosnia-Herzegovina and Croatia in combating impunity for conflict-related sexual violence by successfully prosecuting the crimes. Through interviews with survivors and experts, we document the challenges faced by those who suffered sexual violence and are seeking to gain official status as victims of war crimes.

\section{The Broad Goals of the Project: Seeking Justice}

While in Croatia as a Fulbright scholar 2002-2004, Dr. Dorothy McClellan, Professor of Criminal Justice, began a multi-faceted international collaborative project with Nikola Knez, filmmaker and President of the Croatian Society for Human Rights, examining challenges to democratic nation building in post-conflict society. One key aspect of this project focuses on seeking justice for victims of sexual violence in the Balkan War. 
The overarching goals of the project are:

- To give voice to women who were victims of rape in the Balkan War in an effort to challenge rape as an instrument of terror and military tactic in warfare.

- To seek justice for victims of sexual assault in conflict by granting them the status of victims of war crimes entitled to every means of assistance and support.

- To bring the perpetrators to justice.

- To seek formal governmental compensation for victims.

- To use the testimony of victims to raise public awareness of the need for collective action to create peaceful resolution to international conflicts.

\section{Historical and Political Background for the War}

To place the war in historical and political perspective, it is important to note that the Socialist Federal Republic of Yugoslavia was comprised of six republics and two autonomous regions: The Socialist Republic of Croatia, Slovenia, Bosnia \& Herzegovina, Serbia, Montenegro, Macedonia, and the autonomous regions of Vojvodina and Kosovo. Under the 1974 Constitution, Yugoslavia became a federal union with confederative characteristics. This gave each of the republics the right to secession or separation from the federation.

The Communist Party of Croatia in February of 1990 passed an election law on multi-party elections, enabling the people to have a pluralist democracy. In 1991, the people of Croatia expressed their will in a referendum that favored overwhelmingly (93.5\%) the political independence and separation from Yugoslavia. Shortly thereafter Slovenia, Bosnia and Herzegovina and Macedonia followed suit. The belligerent reaction of the Serbian political and military establishment against Croatia for aiming to establish a sovereign country was swift and brutal. They tried to occupy the whole of Croatia.

After the collapse of the Berlin Wall, the agent states of the Soviet Union sought their independence, separate destinies, and self-determination. The countries of Eastern Europe made a relatively peaceful transition to independence. But in the case of the Socialist Federal Republic of Yugoslavia, that was not so. The Serbians held supremacy in the military and political decision-making process and were determined to resist independence movements. The fact that the capital city of the Socialist Federal Republic of Yugoslavia was Belgrade contributed to the Serbian sense of dominance over the other republics.

The Serbian Academy of Science \& Arts (SANU) had great influence on the political and military establishment of Yugoslavia. The ideology, reflected in their writings, in particular the Memorandum of 1986, sowed the seeds of Serbian hegemony and aggression that had 
been planted long before. The intent of that document was to provide the pseudo-scientific justification for Serbian supremacy suggesting that Serbians were the true and legitimate heirs of the Southern Slavic (Slavonic) tradition, 'Yugoslav' translating as Southern Slav.

The Serbians claimed that they were the purest descendants of the Slavonic tribes that came to Europe in the 6th century and made their way to the Adriatic Sea. That document was obviously intended to lay the political/ideological groundwork for diminishing the rights of each individual republic. In self-pitying prose, the Memorandum is highly reminiscent of Mein Kampf in both its victim tone and belligerent intent. The document advocates radical political action and its principles gave rise to a new political movement. The concept of racial superiority would later reemerge in a campaign of ethnic cleansing that took the form of genocide, rape and sexual enslavement by the Serbians.

The 1986 Memorandum was disseminated to Academies of Science around the world and was widely discussed. By 1991, it was visible that the British, French, and Russians gave the Serbians the political green light to transform the Socialist Federal Republic of Yugoslavia into Yugoslavia. In June of 1991, U.S. Secretary of State James Baker visited Belgrade and assured the political establishment that the U.S. was committed to the "territorial integrity of Yugoslavia" (Cohen, 1992; Bethlehem and Weller, 1997, xxvii; Cohen in Meštrović, 1996, p. 38). He warned the Slovenians and Croatians that "a cold welcome" awaited any action toward independence or secession (Cohen, 1992; Cohen in Meštrović, 1996, p. 38).

Slobodan Milošević's wife, Mirjana, was a member of the inner circle of the Academy of Science and Arts that promoted the ideology of the Greater Serbia (Velika Srpska). Another member of that inner circle was Lubomir Tadić, the father of the recent (20042012) Serbian president, Boris Tadić. The concept of Greater Serbia was always present in the Serbian nation, and can be traced to the Kingdom of Croatia, Serbia and Slovenia (1918) and earlier. Already in 1913, the Carnegie Endowment formed the International Commission to Inquire into the Causes and Conduct of the Balkan Wars. This group consisted of university professors and other prominent individuals from France, Great Britain, the United States, Germany, Austria, and Russia, including three Nobel Prize winners. After three months of investigation in the Balkans, the group released a detailed report in Paris in 1914 detailing horrific atrocities committed against tens of thousands of Albanians in the name of a Greater Serbia (Carnegie Endowment, 1913). Unfortunately, the report's findings were overshadowed by the events of the First World War.

Thus, the 1986 Memorandum incited and fueled deep-seated Serbian nationalism. For hundreds of years, Serbian writers and leaders had expressed a yearning for a Greater Serbia. Former Serbian President Dobrica Cosić, considered to be the most influential member of the Serbian Academy of Science and Arts in the period that the Memorandum was written was called the 'Father of the Nation' by his supporters and the 'Mastermind of Evil' by the civilized world. 
His words capture the dangerous, twisted sentiment underlying Serbian ideology that led inevitably to vicious war crimes of genocide, sexual violence and sexual enslavement, and later, to the denial of responsibility for them: "A lie, trait of our patriotism. We lie to deceive ourselves, to console others; we lie for mercy, we lie to fight fear, to encourage ourselves, to hide our and somebody else's misery. We lie for love and honesty. We lie because of freedom. Lying is the trait of our patriotism and the proof of our innate intelligence. We lie creatively, imaginatively, inventively" (1961) (See Hyseni, April 25, 2016). When the Serbian military entered Vukovar in 1992, they are recorded singing the Serbian song, "Slobo [Slobodan Milošević], send us salad. We'll kill the Croats and eat their meat."

\section{Methodology}

Employing a women and gender studies methodology that includes qualitative interviews with survivors of violence and experts in the field, we sought to examine the legal, psychological, political and social problems of women victims of rape in the Balkan War. The point of this methodology is to engage in research that is activist, that brings about the empowerment of the people being studied, that respects and includes them in the process, and that reaches a broad audience on issues that touch the lives of many in society and require an effective public policy response. In the spirit of this methodology, the products we produce are multi-faceted and aim to reach the academic community, international scholarly and political circles, lawmakers, as well as the general public. These include investigative reports in the media, academic journal articles, international conferences, recorded testimony, and documentary film.

We began by reviewing the literature and interviewing principals to understand the extent and nature of the problem, and the roots of the reluctance of governmental authorities to prosecute the victimizers. To date there are very few scholarly works, full-length documentary films or investigative inquiries in the media that touch on these topics. Documentary film is now integral to academic pedagogy and a powerful tool to reach broad audiences, so a major aspect of this study was to produce a feature length documentary film that relied on interviews with survivors and experts, and used university students for feature scenes and English voiceover, so that students would literally give voice to the victims of rape.

As a young filmmaker and soldier in the Croatian War for Independence, Nikola Knez fought and filmed in Vukovar. Inspired by the United Nations initiative to address crimes of sexual violence against women in armed conflict, the authors undertook a collaboration with the Croatian NGO Women in the Homeland War to return to Vukovar to identify survivors of wartime sexual violence who would agree to be filmed in hopes that these qualitative data could be used to seek justice for all victims by personalizing the gross statistics, and empowering survivors by enabling them to share their long-suppressed experiences. 
In October 2013, as program chair and executive board member of the Alliance of Universities for Democracy, Dr. McClellan succeeded in setting Sarajevo, Bosnia and Herzegovina as the venue for the organization's annual international conference and selecting the conference theme as Democracy \& the University in a Turbulent World with emphasis on regional issues. Under that rubric, we organized plenary and concurrent sessions that addressed regional challenges related to promoting democracy in postconflict society, including the political, social, psychological and legal issues associated with genocide, rape and sexual enslavement in the Balkan War.

The meeting provided an opportunity for the regional organizations working on the problems of women war victims to meet together for the first time to coordinate their efforts, and to reach a broad international audience. The meeting provided the researchers access to documents and persons with direct insights into and knowledge of the problem. In addition to reviewing transcripts of the International Criminal Tribunal for the Former Yugoslavia and reports from Amnesty International, we were now able to conduct interviews with experts from organizations such as the Rosa Center for Women War Victims of Zagreb, Croatia, the Sunćica Center for Women War Victims in Zagreb, the Helsinki Committee of Bosnia-Herzegovina in Sarajevo, the Zenica Centre for Women War Victims, and Medica Zenica, that provides medical and psychological services to rape victims in Zenica, Bosnia and Herzegovina, as well as Prof. Dr. Alma Bravo-Mehmedbašić, a neuro-psychiatrist with the Clinical Center of the University of Sarajevo, whose work on psychotherapy with women victims in the Balkan War has set new standards for developing successful intervention practices.

Working with the Croatian non-governmental organization, Women in the Homeland War, we conducted interviews with 16 ( 14 women and 2 men) self-selected survivors of sexual violence from the besieged city of Vukovar, Croatia, all of whom were participants in a therapeutic support group with a commitment to public disclosure of the crimes they endured. The interviewees signed releases of informed consent, giving permission to include their interviews in a documentary film and articles, and to serve as evidentiary testimony at The Hague Tribunal. The interviews are now also included in the National Archives of Croatia. We produced an award-winning film that addresses the experiences and concerns of people who were raped in the Balkan War, still awaiting prosecution of their victimizers, and still seeking official status as victims of war crimes entitled to moral, spiritual and financial assistance.

In addition to creating a film in Croatian, we undertook the production of an English language version of the documentary to gain international recognition of the problem. Our cast was drawn from the Texas A\&M University-Corpus Christi's renowned Department of Theatre and Film. Our preparation of the American student actors who would contribute the voiceover for the victims included providing them the historical background on the breakup of the former Yugoslavia and the Balkan War, and the extent and nature of the conflict-related sexual violence. 


\section{$5 \quad$ Law \& Politics: Obstacles to Successful Prosecution}

In 2001 The International Criminal Tribunal for the former Yugoslavia (ICTY) "elevated systematic rape from being a mere violation of the customs of war to one of the most heinous war crimes of all - a crime against humanity," second only to genocide (Osborn, February 22, 2001; Amnesty International, February 22, 2001; Barberet, 2014, p. 111). Amnesty International described the verdict in the trial of Dragoljub Kunarac as "a significant step for women's human rights. Sexual enslavement in armed conflict is now legally held to account" (Amnesty International February 22, 2001; Osborn, February 22, 2001; Buss, 2002, pp. 91-99). Kunarac and two other Bosnian Serb officers were found guilty of "the systematic and savage rape, torture, and enslavement of Muslim women in 1992 in the town of Foća in southeastern Bosnia. They were convicted on 19 separate counts" (ICC Trial Transcript - Kunarac. See also Osborn, The Guardian, February 22, 2001; Buss, 2002, pp. 91-99; Merlus, March 12, 2001). According to Osborn,

Dragoljub Kunarac, 40, said to have been involved in a "nightmarish scheme of sexual exploitation," was given 28 years for rape and torture. Radomir Kovać, 39, was sentenced to 20 years for similar crimes. The third defendant, Zoran Vuković, 45, was given a sentence of 12 years because prosecutors were able to produce less evidence in his case. He was, nevertheless, convicted of raping and torturing a 15-year-old Muslim girl who was about the same age as his own daughter (Osborn, February 22, 2001).

Although the ICTY did not treat the mass rapes as genocide, many have concluded from the organized and systematic nature of the mass rapes of the female Bosniak (Bosnian Muslim) population, that these rapes were part of a larger campaign of genocide, and that the Bosnian Serb forces of the Army of the Republika Srpska (VRS) were carrying out a policy of genocidal rape against the Bosnian Muslim ethnic group (Bečirević, 2014, p. 117; Boose, 2002, p. 73; Lončar et al., 2006, pp. 69-71; Weitsman, 2008; U.S. Submission to the UN Security Council, 1993).

The trial of Kunarac was the first time in any national or international jurisprudence that a person was convicted of using rape as a weapon of war. The widespread media coverage of the atrocities by Serbian paramilitary and military forces against Bosniak women and children drew international condemnation.

Yet, 20 years after the war began, Margot Wallström, U.N. Special Representative on Sexual Violence in Conflict, reported that as of 2010 only 12 cases out of the tens of thousands of rapes were prosecuted. As of 2012, only 40 cases had been prosecuted by The Hague Tribunal and local courts (Poggoli, April 30, 2012).

Elena Wasylew, co-author of Old Crimes, Same Suffering, an Amnesty International report, stated that "the women who went through this suffering have received very little help from the government" (Poggoli, April 30, 2012). Politicians are reluctant to address these issues. According to Vera Jovanović, then President of the Helsinki Committee in Bosnia- 
Herzegovina, "This issue of rape victims is kept under wraps. This is still a traditional maledominated society, and these victims are pushed into the shadows.... People pretend they don't exist" (Poggoli, April 30, 2012). Another reason for the lack of justice is that Bosnian Serb leaders "fear a wave of compensation suits from thousands of Bosnian Muslim women whose search for recognition and support from the Bosnian state" has gone unrealized (Zuvela, December 19, 2012).

According to Dr. Stjepan Meštrović, Professor of Sociology, Texas A\&M University, the victims suffered both the crime of rape and the crime of silence. His analysis provides insights into the motives for both:

Except for a few newspaper accounts in Germany, the horrors experienced by the women who were raped by the Serbs were simply not reported, not picked up by the West. I would explain this as follows: The Croats and the Bosnian Muslims were seen as less than European, less than, if you will, white. I think that the rape of white women in the West is something that's taken seriously, but when it is the rape or the mistreatment of women who are minority, and what I'm saying here is that the Croats and Muslims were depicted as a minority, in that sense, it's invisible.... The social construction is always through the lens and the filter of the Western prism, which unfortunately is ethnically biased.

The rapes....were part of an organized tactic of warfare....By raping the women, the Serbs knew that these women would be treated as outcasts....And by causing this kind of upheaval in the family structure, they would weaken and demoralize those families and make it easier to achieve a military victory. I think we have to look at rape, not just as an individual crime, but as a military tactic of aggression (Interview with Dr. Meštrović, College Station, Texas, June 22, 2013; MacKinnon, 1994, p. 85).

The Organization for Security and Co-operation in Europe's (OSCE) Mission to Bosnia and Herzegovina conducted an extensive analysis of conflict-related sexual violence criminal proceedings before the Court of Bosnia and Herzegovina between 2005 and 2013 (OSCE, February 2014). Noting that "many survivors have not received justice and women victims' associations continue to express dissatisfaction with the quality and pace of justice so far," they undertook the study

following nearly a decade of war crimes processing at the State level...to seriously examine the obstacles that persist in the pursuit of justice for the victims of these crimes (OSCE, 2014, p. 8).

The report found that the total number of individuals tried for conflict-related sexual violence as of 31 December 2013 in Bosnia-Herzegovina state courts was 71, and only 68 individuals were tried before the U.N. Security Council's International Criminal Tribunal for the former Yugoslavia (ICTY). According to the study, "111 cases involving conflict-related sexual violence have been addressed by the criminal justice system in $\mathrm{BiH}$." Of these, 36 cases were concluded, "convicting 33 perpetrators and acquitting 12 individuals.... At the 
end of 2013, indictments in a further 18 cases had been confirmed - although in three of those cases the fugitive remained at large" (OSCE, 2014, p. 5). The report acknowledges that

the overall number of indictments for sexual violence raised by the BiH Prosecutor's Office is low in comparison to the prevalence of such crimes in the conflict - during which an estimated 20,000 women and girls and an unknown number of men and boys were victimized....The outstanding number of unresolved cases concerning conflict-related sexual violence and their relative complexity...frustrates victims' wishes to know what progress is being made in investigating the crimes against them (OSCE, 2014, pp. 5-6).

The report concludes that "legal and practical hurdles" such as lack of available evidence and suspects and limited capacity to investigate and prosecute cases are the main obstacles to successful prosecution (OSCE, 2014, p. 6).

The OSCE report acknowledges that

the majority of perpetrators of sexual violence continue to enjoy impunity. The failure to provide accountability for these crimes will continue to have a debilitating impact on survivors of sexual violence and serve as an impediment to post-conflict reconciliation and the establishment of full respect for human rights and the rule of law in $\mathrm{BiH}$ (OSCE, 2014, p. 9).

With regard to the ICTY's even weaker record of prosecution of such cases, in January 2014 four defendants were still on trial for war crimes--Goran Hadzić, Radovan Karadžić, Radko Mladić and Vojislav Šešelj, and 10 cases were still before the Appeals Chamber (OSCE, 2014, p. 10).

By 2016, of these four defendants, only Karadžić was convicted in March 2014 on 10 of 11 charges, one of which was "Inhumane Acts" that included sexual violence (Hume, March $24,2016)$ and sentenced to 40 years. He is appealing his conviction. In March 2016, Šešelj was acquitted on all counts (BBC, March 31, 2016). Mladić's trial is ongoing and none of the charges directly addresses sexual violence (Justice Report, June 13, 2016; Milutinović, June 13, 2016). Hadzić has received an indefinite stay of trial proceedings due to alleged medical problems (Nikolić, April 5, 2016). The ICTY has a limited mandate since it was established as a temporary tribunal. Therefore, it has focused on prosecuting only the highest-level accused and referring other cases to courts in the former Yugoslavia. It no longer issues war crimes indictments and is completing these last few cases.

The poor record of successful prosecution of the war crimes of genocide, rape, and sexual enslavement can best be understood by examining the creation of the U.N. Security Council's International Criminal Tribunal for the former Yugoslavia (ICTY). Under the authority of the Security Council, the Tribunal was hastily structured in 1993 "to stop aggression and reestablish peace and security." The U.S. played a key role in drafting the 
proposals regarding the Tribunal and the Security Council Resolutions that led to the Tribunal's establishment, as well as the all-important Rules of Procedure. The legislative history of this process is unclear because deliberations were secret. According to international legal expert Edward Slavko Yambrusić, the Tribunal took a controversial stance by replacing the concept of aggression with that of "joint criminal enterprise" (Yambrusić, 2010, p. 17). The legal doctrine of joint criminal enterprise used by the ICTY to prosecute political and military leaders for mass war crimes committed during the Yugoslav wars (1991-1999) is highly disputed in legal circles.

As renowned legal scholar M. Cherif Bassiouni explains, "This doctrine considers each member of an organized group individually responsible for crimes committed by the group within its common purpose or plan" (Bassiouni, 2011, p. 18), a charge both difficult to prove and, in the case of the ICTY, even used against those persons who were engaged in legal self-defense. According to Yambrusić, it is "a conspiracy charge historically meaningful only in the context of the crime of aggression, initiating or waging a war of aggression, i.e. crimes against the peace." He argues that "contrary to the Nuremberg and U.N. Charters, the ICTY applied it to 'defenders"' (Yambrusić, 2010, p. 42).

The Security Council failed to make the essential distinction between the aggressor, a war criminal committing a jus cogens crime (a crime that violates a fundamental principle of international law from which no derogation is permitted) and the defendant-victim of the crime lawfully engaged in self-defense. This formulation resulted in a poor record of successful prosecution of cases of genocide, rape, and sexual enslavement, and an uncertain political future for the region.

According to both Bassiouni and Yambrusić, the U.N. Security Council's actions in creating the ICTY were politically motivated and had the intended effect of equating the victim and the aggressor. The Security Council, contrary to the U.N. Charter and the general principles of international criminal law, tried to resolve an international conflict of massive proportions by judicial means. This was an attempt to 'judicialize' the conflict over which it would otherwise not have legal jurisdiction since the crime of aggression is outside the purview of the ICTY.

Bassiouni writes:

Moral equivalency made questions of justice extraneous to, even distracting from, the quest for peace based on the balance of power and nothing more .... The choice of peace or justice must be recognized as a false dichotomy that undercuts the attainment of either (Bassiouni, 2014, p. 104).

In failing to make the essential distinction between the aggressor, a war criminal, and the victim of the crime engaged in self-defense, the result was peace without justice (Yambrusić, 2010). Bassiouni's remarks on the concept of moral equivalency conclude: 
No peace can last, no court prosper, under such a theory; ultimately it must be the aim of the international community not to choose, tragically, between peace or justice, but to pursue both (Bassiouni, 2015, p. 105).

Another serious obstacle to combating impunity for conflict-related sexual violence was the ICTY's doctrine of "command responsibility" put forward in Article 7 of the ICTY Statute that centers responsibility on only a handful of high-profile military and political leaders,

on those who had real power, whether military or political, and who, by their decisions or omissions, led to commission of the crime by its direct perpetrators. According to that doctrine, the main culprits for crimes possibly committed by anonymous perpetrators are precisely those in positions of power. This approach and the doctrine of joint criminal enterprise met with resistance due to an alleged lack of legal grounds, as well as politicization, particularly in the countries that had waged defensive wars (Josipović, 2006, p. 147).

Although Milošević was the principal architect of Serbian aggression, he was not indicted by the ICTY until 2001, ten years after the war began. Showing clear disdain, Bassiouni argues that in the interest of seeking a "political peace" deal, Milošević was permitted to wreak havoc in Croatia, Bosnia and Herzegovina, and in Kosovo before he was finally indicted (Bassiouni, 2014, pp. 100-103). Yet the ICTY induced national judiciaries to adjust their standards to those set by the ICTY. In Croatia, certainly, there was understandable reluctance to prosecute their own, individuals who were seen as defending the country against external aggression. In addition, Croatian law does not acknowledge the principle of "command responsibility," thus making it difficult to comply with the ICTY statute.

Political pressure was put on Croatia by the international community, especially the European Community (now the European Union), to amend an existing amnesty law and to adopt the Law of Forgiveness from Criminal Prosecution or Proceedings in the Course of Armed Conflict in Croatia. The latter was intended "as a conciliatory gesture toward the Serbs so as to better facilitate peace negotiations initiated in London in August 1992" (Nizich et al., 1995, pp. 78-80). Article 2 of the "law of forgiveness" states that crimes against humanity, genocide, and war crimes will not be exempt from prosecution. But the Croatian public was outraged that President Tudjman bowed to pressure and signed it into law. The public correctly predicted that the law of forgiveness would, in fact, lead to failure to prosecute perpetrators of war crimes of sexual violence.

According to Marija Slišković, Director of the Croatian NGO Women in the Homeland War, the court in Croatia failed to provide support for the Croatian victims of Serbian sexual violence in conflict. In an attempt to turn the page on the war, Croatia granted amnesty to Serbian war criminals. Slišković argues that this had the effect of permitting individuals who were criminals to walk free, to run for and hold office in the post-war Croatian government, and for the country to turn its back on the victims of their crimes. Human Rights Watch reported that Tudjman granted hundreds of pardons under the Amnesty rule 
already in 1993, and that "investigations into the cases of an additional 2,516 individuals accused of similar crimes were stopped and charges not brought. Of the 2,516, 2,031 were alleged to have been members of Serbian armed forces and paramilitary groups" (p. 80). Slišković states:

When we talk about amnesty, I think first of the 14th Amendment of the U.S. Constitution. It says that anyone who rebelled against the United States or any state within the United States cannot participate in public service or act politically at the decision making level of government. In Croatia that is not the case. In fact, the reverse is true. People who were on the side of the aggressor, who held high positions in the occupying army, currently serve as members of the Croatian Parliament.... It is unacceptable for people who were terrorists and members of the Serbian army to serve in the Croatian parliament and to direct their constituents in the same way they did in 1991.

After the war and the establishment of a democratic political society, Croatian victims of sexual abuse did not gain recognition of their status as victims of war crimes.... This act of omission has resulted in the victims having to cope alone with their victimization (Interview, Vukovar, August 13, 2013).

In 2005, the OSCE reported that

The Croatian State Attorney suspended over 800 criminal proceedings which had been conducted for war crimes since the nineties.... So far the Law of Forgiveness, relating to participation in armed rebellion, has been applied to 22,000 Serbs (Josipović, 2006, p. 152).

According to the 2005 report of the OSCE Mission to Croatia authored by Ivo Josipović, who later became the third President of Croatia (2010-2015),

Croatia since 1991 has engaged in the large-scale prosecution of war crimes. Nearly 5000 persons have been reported and over 1700 have been indicted. Final verdicts have been entered against 800 to 900 persons, of which more than 800 were convicted, while approximately 100 were acquitted .... The overwhelming majority of proceedings were against Serbs for crimes against Croats and the vast majority of convictions were obtained against in absentia Serb defendants (Josipović, 2006, p. 152)

Investigations and cases in 2004 were pending against another 1400 to 1500 persons. As the years pass, it becomes increasingly difficult to successfully prosecute cases because of complexities in the law, defendants who cannot be located, evidence that has been lost, and victims who have given up hope or died. 
It is important to note that Croatian legislation did not include the offense of "crimes against humanity" until 2004, when amendments to the Criminal Code introduced this offense so that it follows the Rome Statute of the International Criminal Court.

As one carefully examines the original Croatian legislation, one finds "Genocide" (Article 156 of the Criminal Code), "War crime against civilians" (Article 158), "War crime against wounded and sick" (Article 159), "War crime against prisoners of war" (Article 160), but no specific mention of rape and sexual enslavement as a crime against humanity (Josipović, 2006, pp. 157-158). Josipović argues that "It is hard to imagine a situation in which such crimes could not have been considered as one of the forms of war crime in Croatian legislation" (Josipović, 2006, p. 157). But the absence of specific mention of it, no doubt helps to explain the claims made by many survivors that their cases were hampered by complex legal issues that militated against successful prosecution and conviction.

\section{Public Policy Initiative}

In a concerted collaborative effort to move our project forward to achieve the goals of challenging rape as an instrument of terror in warfare and gaining for the survivors the status of victims of war crimes, we and the NGO Women in the Homeland War succeeded in receiving the support of the Croatian Ministry of Veteran Affairs and the Mayor of the City of Zagreb to press the Parliament for legislation to compensate survivors of wartime sexualized violence. The Minister and Mayor hosted a public screening of our documentary film, Sunny's Story: Rape as an Instrument of Terror in War, to solidify public support. The film premiered at the Europa Theatre in Zagreb, Croatia in March of 2014 to a standingroom-only crowd. The 16 survivors featured in the film were seated in the front row wearing white armbands. They rose to their feet, holding one another's hands. They spontaneously raised their clasped hands high to the cheers of the more than 500 guests. They were then presented with bouquets of red roses by the Mayor and applauded for their courage. The Minister of Veteran Affairs spoke movingly. He acknowledged for the first time that he, too, had been a victim of sexual violence as a prisoner of the Serbian military. The film and event received extensive media attention. The Croatian and English versions of the film posted online have since had more than 84,000 views.

In late May of 2015 the film was screened before the Croatian Parliament and a sevenhour debate ensued. At the end of the highly emotional session attended by many of the victims who appear in the film, the parliamentarians voted (86 votes in favor and three abstentions) to enact a law that provides compensation to Croatian victims of sexual war crimes, the most far-reaching legislation of any country in the region. The Law on Rights of Victims of Sexual Violence During the Armed Aggression on the Republic of Croatia During the Homeland War entitles survivors to a one-time compensation of approximately $13,000-$ 21,000 Euros (depending on whether they became pregnant after the rape or were minors at the time of the crime), a monthly stipend of about 400 Euros, health insurance, counseling, and legal aid (Associated Press, May 29, 2015; Cartier, July 23, 2015). In 
contrast to Bosnia and Kosovo, the law provides compensation out of the national budget. In Bosnia, victims of rape must seek compensation from their perpetrators during criminal proceedings. In April of 2015, in a landmark case, a Croatian woman who was raped in Bosnia in 1992 at the age of 15 was the first person whose perpetrators were ordered to compensate their victim for rape $(13,520$ Euros) (Lajka, April 23, 2015), but they may be too poor to pay.

\section{Excerpts from Victim Testimony Recorded in Vukovar, Croatia, August 14, 2013}

Testimony of Woman 1:

I am Jacqueline. I lived in Vukovar. I was 18 years old in 1991 when the war began. My daughter was 8 months old. When Vukovar was occupied by Serbian soldiers, they kept me in an apartment there alone with my daughter and my eight-year old sister. After multiple rapes and torture, they took me to a concentration camp. They kept me, my sister and my child there for many months. My sister and I were raped and tortured every day. We suffered terribly. They would rape me and throw their heavy uniforms on my small baby to muffle her cries. By some miracle, she survived.

After being released from the concentration camp...friends of the people who tortured me in the camp threatened that my daughter would have the same destiny as me. So once again I had to escape my city and again be a refugee. I continue to live as a refugee, in fear that my daughter could endure my same fate.

When I got out of the camp in 1992, I gave a statement to the Court about my war time experiences, about everything that happened to me. The Court gathered evidence from 1992 until 2007. In that time, they apprehended only two criminals and nothing has yet been decided about them. I have not received any satisfaction of my claims. I have been a victim of war crimes without any rights...no recognition of what I endured, for all these years.

Testimony of Woman 2:

We were forced to tie a white cloth to the gate of our house that indicated we were Croatian. I lived in my home with my mother, father, husband and 9-year old son. The Serbs entered our courtyard whenever they wanted, they did what they wanted, they mistreated us as they wanted. They took away anyone whom they chose....

My family was gathered in my apartment. The soldier grabbed me. I begged him to leave me alone for the sake of my child. He said these words to me: "First l'll kill your mother, then I'll kill your father, then I'll kill your husband. I'll leave you and your son for my pleasure. He raped me and left. I stayed in the room crying. 


\section{Testimony of Woman 3:}

The rape, harassment and abuse began in the camp in Sremska Mitrovitsa. They did it every day. I wasn't raped by Serbs who came from Serbia, Serbian soldiers or Chetniks. I was raped by the Serbs from my own city, Vukovar, with whom I lived my whole life and with whom I had shared the good and the bad. After numerous rapes, they took me to a room for execution. There I found my daughter with her four-year old son--my grandson. My grandson was taken away and we have never seen him again. My daughter had to watch me being raped and I had to watch the rape of my daughter.

I did not return to Vukovar because the Serbs who killed, raped, tortured and robbed us still live in that city. Not one of them has yet been held accountable for his crimes. When inmates of the camps gather each year to commemorate our suffering, Vukovar Serbs scornfully laugh and humiliate us.

Testimony of Woman 4:

Many Serbian soldiers stood in front of my house. When I stepped outside I saw a neighbor and my father-in-law lying on the ground with the Serb's rifles pointed at their heads. The soldiers said to me: You haven't done anything to us but you're guilty because you're Croatians. One of the soldiers told me to take my clothes off. I said, "Please don't do anything to me." He said "Take off your clothes or l'll kill your mother-in-law and daughter. I couldn't do anything other than remove my clothes. He put his penis in my mouth....

Testimony of Woman 5, Medical Director of Post-Surgical Care, Vukovar Hospital:

It was an unbelievable situation. We were truly in Hell. We saw and lived through something you could never imagine in your life. What we experienced in Vukovar cannot be captured in any film.... There were approximately 4,000 civilians and patients who came to the hospital to seek refuge and safety. Instead they found death. Whoever came to the hospital was transported to concentration camps or taken like lambs to the slaughter to Ovčara, for mass liquidation.

They kept me in the village of Negoslavči for 48 hours. I was at the mercy of anyone who wanted me... After that, I was transported to the concentration camp Mitrovica in Serbia. When I arrived they placed me in solitary confinement. Immediately, the walls began to echo with the horrifying screams of people experiencing waterboarding and electrical torture. Whines, cries, people pleading for their lives.... Pure horror....

Testimony of Woman 6:

Serbo-Chetniks came to my home to arrest me.... Because I am Croatian I had to put a white cloth on the gate of my house, signaling to everyone that I was Croatian and free for the taking. 
I was forced to live with four Serbs. They raped me whenever they wanted. The Serbs said that all Croatian women have to be fucked so that they give birth to Serbian children. One day there were eight of them. They put me through painful interrogations and then they all raped me.

Testimony of Woman 7:

My street was predominantly inhabited by Serbs. So this part of the city was less shelled. Serbs had their wives and children seek safe haven in the Yugoslav Army base when they were shooting at us. A Serbian soldier told me that my father was killed in the apartment. I went to the apartment and found my father dead on the couch. Above him on the wall was written "We Serbs killed your dad. This is Serbia." ...The next morning I found my husband dead in the apartment. Then two Serbian soldiers put their hand grenades and Kalashnikovs on my kitchen table. One soldier ordered me to leave the room with the other. After the first did his job on me, then the second soldier took his turn.... I cry and cry because all of my relatives died in Vukovar.

Testimony of Woman 8:

When I walked into my house, nine Serbian soldiers were there. Everything smelled of alcohol, they were all drunk and yelling like animals. Immediately they stripped away all of my clothes, and I was naked in seconds. Countless hands started touching and probing me all over my body. They covered my eyes and nose with a cloth. I began choking.... They threw me to the floor. While one man held the cloth tight, they put their penises in my mouth. I lose my voice when I talk about it. When I lost consciousness, they threw me on a concrete slab. I don't know how long the rapes lasted. They committed perversions on me. 20-40 men. When they took me out in the backyard, I knew they would kill me. At that moment I thought: Dear God, help me! They pushed me and I fell to the ground. I heard a burst of machine-gun fire and then another round. They yelled with pleasure like savages and left. They thought I was dead. I lay on the ground, stiff with fright, cold and pain. I lay on the ground petrified.

They killed 17 members of my family. Now whenever there is a celebration, none of my relatives are present. Their places at the table are empty and deserted. I have no words to express it.... My husband and I had shown such love to everyone. We welcomed them into our home. And those Serbs repaid our kindness in such a way...

Testimony of Woman 9:

On October 2nd, 1992 three Serbs came to take us into custody.... I was taken to Serbian headquarters for questioning. In front of that building, my cousin was lying on the ground dead. His brain was oozing out of his head. 
After interrogation they took me to the Velopromet concentration camp in Vukovar, a collection of old hangars. The men were led away for torturing and killing. The women were taken to be raped. I started to cry and begged them not to. One Serbian soldier said, "It's your choice. It's me or ten others and then we'll put you before a firing squad." It was terrifying. I screamed and cried.... Afterwards my neighbor held my head while I vomited. After a few days three other Serbian soldiers came.... (She's crying.) They raped me every day. Every day.

I returned to Vukovar in 1998. I encountered one of my rapists on the streets of Vukovar. On one occasion I had an umbrella and I began to beat him and scream. He fled. After that the police began an investigation. I provided the police with all the evidence of the crime. The fiends were arrested, but after just one week they were released pending trial. Radi Ivković sold his house in Vukovar and fled to Serbia. Dusan Ivković, who worked as a police officer, was suspended from his job, but the union paid his entire salary as well as providing him lawyers for his defense. I saw him a few times in the city, but then he fled to Canada.

I always asked myself, why did this happen to me? Now I know that I 'm not the only one to whom this happened. Now I think that we have to be thankful to God that he kept us alive and that he gave us the strength to speak out and let the world know what happened here.

A few days ago I found out that my husband was raped in the Serbian concentration camp Begejči along with other detained men. The world doesn't know anything about this!

Testimony of Woman 10:

On November 6th, 1992 police in blue uniforms pulled up to our workplace, a veterinary station, in a van. They took me and my colleagues to a military headquarters in Negoslavči... There we were interrogated one at a time. We were locked in the basement of the headquarters. We found a villager named Ante Korać. I didn't see what they did to him, but I heard his screams and cries. Another friend was carried out covered in blood. They continued to beat him in the hallway with shovels. I was the fourth in line for interrogation. They were vicious. They mocked me. They beat me. They held a cattle prod to my neck.... One of the interrogators was dressed in a military uniform.... He and another young man about 18 years old, a member of the Chetniks from Negoslavči, raped me. One after the other.

Dragutin Fočić was later found in a mass grave in Vukovar, and the other five, no one still knows where they are. They are officially designated as "missing persons."

Testimony of Woman 11:

The Chetniks took my family into custody. They did to us what they wanted. My Serbian godfather who lived next door did nothing to save us. Perhaps the only 
thing he did was to keep us from ending up in a mass execution, because no one else who came through interrogation came back alive. No one. Never.

Fifteen of us were crammed into a truck,... men and women. They transported us to the concentration camp in Mitrovica. As soon as we arrived they jumped on us like rabid wild beasts. Men were separated to one side and stripped naked. We women were taken to Room 14 where I was imprisoned for one month. I don't know how I survived it all....

The man who beat my sons and husband was named Marko Crevar. One of my sons is dead. The other has been declared "missing." I am unable to live with all that happened. Every day I pass by the house where they tortured and killed people....where they tortured and killed my two sons. Every day...I hear their cries and calls for help.... How can I forgive those Serbs? I accept if God would like to punish me for that, but I cannot forgive them.

After I returned to Vukovar, I encountered one of my rapists. When he saw me, he froze. When I saw him I froze, but I found my courage because I was in my own country now. I said, "How do you have the nerve to sit and work here after everything you did - from torturing people to raping us?" The nerve. He has worked in the Vukovar City Hall for 12 years. I filed my lawsuit against him six years ago and it still hasn't been processed. The police say that there is insufficient proof to file charges. I, who endured all of these horrors and torture, am I not proof enough?

My husband and were walking in the city and we encountered the Mayor. He embraced us like friends. And I asked him, "Mayor, does that Chetnik still work in your office? The Chetnik's name is Vlado Vezmar." The Mayor stepped back, withdrawing his hands from our shoulders and walked away without answering. Can you imagine that? Whose side is he on? My sons are gone and the Chetnik is more important than my sons. My sons died fighting and defending Croatia and the Chetnik has now been rewarded with a job!

Testimony of Woman 12:

They collected many of us women on the street. The first woman had to carry a white cloth that symbolized to all that we were free for the taking for sex. They walked us through the city. They separated the men from the women, the children from their mothers. The city was full of dead people. They were killing people on all sides of us. It was a horror. There were passionate cries. People were killed en masse. People without a head, severed body parts all around, streams of blood on the road. A Serbian soldier said, "So, now you see what we have done today."

Pregnant women had to stand while Serbian soldiers threw machetes around them. Everyone else had to watch. The soldiers raped me in the nursery. The first soldier was a homosexual. He did awful, perverted things that I cannot talk about. It is a 
disaster that has haunted me for years. I cannot even pronounce the words of what they did to me. They were dirty and disgusting. There were certainly 15 or 16 Serbian soldiers. They all raped me, one after the other, one after the other. It was awful, painful, and humiliating.

I want to tell the whole world that we want justice. We want the truth to be told and we want the criminals to be punished. These Serbian atrocities and crimes against civilians cannot under any circumstances be justified in the civilized world.

Testimony of Woman 13:

There were 102 people imprisoned in a cellar. They were brought to the building behind me, one by one to be interrogated and tortured.... The grandfather who was born in 1916 was so badly beaten that his eyes fell out of his head. They beat him just because he was a Croat. The mother of Mato Mitrović was slaughtered with a knife, she had her throat slit, just because she was Croatian. We found her remains behind the house. One day many others were loaded into a truck and transported to a school. When I arrived at the school the next day to feed them, everyone was gone. They were all slaughtered. After that I could never go into that basement again.... I cannot even look that way. I just walk by and still hear and see the people crying, screaming, beaten, bloody.

All Serbs are cowards. They were horrible. Yet when someone files a lawsuit against them for these dreadful crimes, each of the Serbs has four lawyers who defend them. You see what animals the Serbs are, they still dream of Greater Serbia and want another war.

Testimony of Woman 14:

My fear was so great that I wasn't conscious that I was urinating and defecating. What encouraged me most was the voice of Radio Vukovar, the only radio station operating. Their reports comforted me and enabled me to endure. It gave us hope that the situation would improve. They encouraged us to remain courageous and brave. When the bearded Chetniks came, they lined us up against the wall. The streets were full of corpses. They collected them with bulldozers. The Serbian Major Sljivančanin told everyone that Serbs were immediately free to go home. Individuals who considered themselves Yugoslavs could leave in two or three days. Croatians, perhaps after a week or never.... They made me collect feces with my bare hands. I was forced to drink alcohol and then they raped me.

\section{Conclusion}

The first U.S. Ambassador to newly independent Croatia was Peter W. Galbraith, a highly educated and sensitive man who served from 1993 to 1998. In an emotional interview he gave in the summer of 1993 on Croatian National Television (HRT), he expressed his shock and outrage at the war crimes: 
One of the things that seems terribly important to me in this whole process is that at the end of the day justice be done. Terrible crimes have been committed. Crimes against the City of Vukovar, crimes against the Croatian soldiers who were in the hospital in Vukovar. Each individual there having the most horrible stories of what happened when the enemy came into villages, rounded up people, destroyed homes, when neighbors went out and killed neighbors, raped women, killed children, rounded up men and put them into death camps. All of these are crimes against humanity, they are violations of very fundamental principles of international law, and equally important, they go against all standards of human decency.

There cannot be a peace agreement here which involves an amnesty for those who committed these crimes. That would be unacceptable. The weight of the evidence is going to be overwhelming. It will have its own momentum.

Twenty-five years have passed since the war began and the process of seeking justice is still underway but, for most, justice remains unrealized. These individuals bravely endured terror and trauma, war crimes of rape, crimes against freedom, and disregard of the laws of the state and humanity. We are indebted to the victims and survivors and thank them for their sacrifice, for surviving these evils to serve as witnesses. We thank them for sharing the truth in hopes that it will awaken our collective conscience. They sacrificed for the freedom and independence of their countries in wartime, when their countries did not have the power to protect them, and today when they struggle for recognition and justice.

\section{References}

Amnesty International. (2001, 22 February). Bosnia-Herzegovina: Foća Verdict - Rape and Sexual Enslavement are Crimes Against Humanity, [online] Available at: http:/www.web.amnesty.org/ai. nsf/Index/EUR630042001?OpenDocument\&of=COUNTRIES/BOSNIA-HERZEGOVINA [Accessed 16 June 2016].

Amnesty International. (2012, March). Old crimes, same suffering: No justice for survivors of wartime rape in northeastern Bosnia and Herzegovina, [online] Available at: https://www.amnesty.org/en /documents/ eur63/002/2012/en/ [Accessed 15 June 2016].

Associated Press. Croatia Passes Law Compensating Rape Victims from 1990s War, [online] 29 May 2015. Available at: http://www.dailymail.co.uk/wires/ap/article-3102711/Croatia-passes-lawcompensating-rape-victims-1990s-war.html [Accessed 10 June 2016].

Barberet, R. (2014). Women, crime and criminal justice: A global enquiry. New York: Routledge.

Bassiouni, M.C. (2011). Crimes against humanity: Historical evolution and contemporary application. Cambridge: Cambridge University Press. http://dx.doi.org/10.1017/CBO9780511976537 
Bassiouni, M.C. (2014). Real Justice or Realpolitik: The Delayed Indictment of Milošević. In: T. W. Waters, (ed.), The Milošević trial: An autopsy. Oxford University Press, pp. 92-105. http://dx.doi.org/10.1093/acprof:oso/9780199795840.003.0006

BBC, March 31, 2016. Serbia Radical Vojislav Šešelj Acquitted of Balkan War Crimes, [online] Available at: http://www.bbc.com/news/world-europe-35933468 [Accessed 16 June 2016].

Bečirević, E. (2014). Genocide on the Drina River. New Haven: Yale University Press. http://dx.doi.org/10.12987/yale/9780300192582.001.0001

Bethlehem, D. and Weller, M. (1997). The Yugoslav crisis in international law. Cambridge: Cambridge University Press.

Boose, L. (2002). Crossing the River Drina: Bosnian Rape Camps, Turkish Impalement, and Serb Cultural Memory. Signs, University of Chicago Press, 28(1): 71-96. http://dx.doi.org/10.1086/340921

Buss, D. (2002). Prosecuting mass rape: Prosecutor v. Dragoljub Kunarac, Radomir Kovać and Zoran Vuković. Feminist Legal Studies, Springer, 10 (1): 91-99.

Carnegie Endowment. (1913) Report of the international commission to inquire into the causes and conduct of the Balkan Wars [pdf] Available at: https://archive.org/details/reportofinternat00inteuoft). [Accessed: 17 June 2016].

Cartier, Cyrille. (2015, July 23). Croatia's Wartime Rape Law Raises Hope and Doubt, Women's eNews [online] Available at: http://womensenews.org/2015/07/croatias-wartime-rape-law-raises-hope-anddoubt/ [Accessed 19 June 2016].

Center for Women War Victims. (2003). Women recollecting memories: The Center for Women War Victims ten years later, $2^{\text {nd }}$ Edition, Zagreb, Croatia.

Cohen, P. (1992). The U.S. Role in Catalyzing and Sustaining Serbian Aggression, Report to Clinton-Gore Transition Team, [online] December 17, 1992. Available at: http://www. siliconinvestor.com/ readmsgs.aspx ?subjectid=26815\&msgnum $=3655 \&$ batchsize $=10 \&$ batchtype $=$ Next $\quad$ Accessed 16 June, 2016].

Cohen, P. (1996). Ending War and Securing Peace in the Former Yugoslavia. In: Meštrović, S., ed., Genocide after emotion: The post-emotional Balkan War, New York: Routledge, pp. 31-50.

Cohen, P. (1996). The Complicity of Serbian Intellectuals. In: Cushman, T. and Meštrović, S., eds., This time we knew: Western responses to genocide in Bosnia. New York University Press. pp. 39-65.

Hume, T. (2016, 24 March), Radovan Karadzić Found Guilty of Genocide, Sentenced to 40 years, [online] Available at: http://www.cnn.com/2016/03/24/europe/karadzic-war-crimes-verdict/ [Accessed 15 June 2016]. 
Hyseni, M. (2016, April 25). Kosovo is Albanian Jerusalem, Not Serbia's. News Blaze, [online] Available at: http://newsblaze.com/thoughts/opinions/kosovo-is-albanian-jerusalem_56359/ [Accessed 17 June 2016].

Josipović, I. (2006, March) Responsibility for War Crimes Before Establishment of National Courts in Croatia. International Review of the Red Cross, V88, 861:145-168 [pdf] Available at: https://www.icrc.org/eng/assets/files/other/ irrc_861_josipovic.pdf [Accessed 16 June 2016].

Lajka, A. (2015, April 23). Balkan Wartime Rape Victims Continue to Face Hardships Decades After Conflict, [online] Available at: https://news.vice.com/article/balkan-wartime-rape-victims-continue-to-facehardships-decades-after-conflict [Accessed 19 June 2016].

Lončar, M., Medved, V., Jovanović, N. and Hotujać, L. (2006). Psychological Consequences of Rape on Women in 1991-1995 War in Croatia and Bosnia and Herzegovina [online] Croatian Medical Journal 47 (1): 67-75. Available at: http://www.ncbi.nlm.nih.gov/pmc/articles/PMC2080379/ [Accessed 16 June 2016].

MacKinnon, C. (1994). Turning Rape into Pornography: Postmodern Genocide. In: Stiglmayer, A., Faber, M., Enloe, C., and Gutman, R., eds., Mass rape: The war against women in BosniaHerzegovina. Lincoln, Nebraska: Bison Books, University of Nebraska-Lincoln, pp. 73-187.

Merlus, J. (2001, March 12). Judgment of Trial Chamber II in the Kunarac, Kovać and Vuković Case. The American Society of International Law, Volume 6, Issue 6. [online] Available at: https://www.asil.org/insights/volume/6/issue/6/judgment-trial-chamber-ii-kunarac-kovac-andvukovic-case [Accessed 16 October 2016].

Milutinović, R. (2016, June 13). Last Mladić Trial Witnesses to Start Testifying. Justice Report, [online] Available at: http://www.justice- report.com/en/cases/mladic-ratko-news-analysis-and-opinion [Accessed 13 June 2016].

Nikolić, I. (2016, April 4). Goran Hadzić War Crimes Trial Postponed Indefinitely, [online] Available at: http://www.balkaninsight.com/en/article/hague-tribunal-postpones-goran-hadzic-trial-idefinitely--0405-2016. [Accessed 16 June 2016].

Nizich, I., Markić, Ž., Laber, J. (1995). Civil and political rights in Croatia, [pdf] Human Rights Watch /Helsinki. Available at: https://www.hrw.org/reports/pdfs/c/croatia/croatia95o.pdf [Accessed 16 June 2016].

Organization for Security and Cooperation in Europe (OSCE) Mission to Bosnia and Herzegovina. (2014, February). Combating impunity for conflict-related sexual violence in Bosnia and Herzegovina:

Progress and challenges, OSCE, [pdf] Available at: http://www.osce.org/bih/171906 [Accessed 16 June 2016]. 
Organization for Security and Cooperation in Europe (OSCE) Mission to Croatia, (2005, 26 April). Background report: Domestic war crime trials 2004, OSCE [pdf] Available at: http://www.osce.org /zagreb/28339?download=true [Accessed 16 June 2016].

Osborn, A. (2001, February 22). Mass Rape Ruled a War Crime, London: The Guardian, [online] Available at: http://www.tribuneindia.com/2001/20010224/world.htm\#6 [Accessed 16 June 2016].

Parrot, A., and Cummings, N. (2008). Sexual enslavement of girls and women worldwide. Santa Barbara, CA: Greenwood Publishing Group.

Poggoli, S. (2012, April 30). Peace, Justice Elude Rape Victims of Bosnian War. National Public Radio, [online] Available at: http://www.npr.org/2012/04/30/151688541/peace-justice-elude-rape-victims-ofbosnian-war [Accessed 16 June 2016].

Stiglmayer, A., Faber, M., Enloe, C., and Gutman, R., eds. (1994). Mass rape: The war against women in Bosnia-Herzegovina. Lincoln, Nebraska: Bison Books, University of Nebraska Press.

United Nations International Criminal Tribunal for the former Yugoslavia. (2001, February 2). Kunarac, Kovač and Vuković Judgment and Case Information Sheet [pdf] Available at: http://www.icty. org/x/cases/kunarac/cis/en/cis_kunarac_al_en.pdf [Accessed 16 June 2016].

United Nations International Criminal Tribunal for the former Yugoslavia (1997,18

September). Report of the international tribunal for the prosecution of persons responsible for serious violations of international humanitarian law committed in the territory of the former Yugoslavia since 1991.

United Nations Office for the Coordination of Humanitarian Affairs. (2008). Sexual and gender-based violence in conflict: A framework for prevention and response [pdf] Available at: http://www.unfpa. org/sites/default/files/pub-pdf/GBVIE.Minimum.Standards.Publication.FINAL_.ENG_.pdf [Accessed 16 June 2016].

U.S. submission of information to the United Nations Security Council. (1993). Seventh Report on War Crimes in the Former Yugoslavia, Part II, [online] Available at: https://www.phdn.org/archives/ www.ess.uwe.ac.uk/documents/sdrpt7b.htm [Accessed 16 October 2016].

Weitsman P. (2008). The Politics of Identity and Sexual Violence: A Review of Bosnia and Rwanda. Human Rights Quarterly, 30 Available at: http://muse.jhu.edu/article/242419 [Accessed 16 October 2016]. http://dx.doi.org/10.1353/hrq.0.0024

Yambrusić, E. (2010). Peace at the price of justice \& human dignity. Zagreb, Croatia: Croatian Cultural Council.

Zuvela, Maya. (2012, 19 December). Bosnian War Rape Victims Suffer in Silence, Wait for Justice, Reuters, [pdf] Available at: http://www.reuters.com/article/us-bosnia-rape-idUSBRE8BI0SD20121219 [Accessed 16 June 2016]. 
Website:

Knez, N. and Posavina, I. (2014). Sunny (Sunćica). [online] Rape as an Instrument of Terror in War Available at: https://www.youtube.com/watch?v=vMOddqLyl3M [Accessed October 26, 2016]. 